\title{
DIVIDEND POLICY AND STOCK RETURN OF THE NON-FINANCIAL COMPANIES: EMPIRICAL EVIDENCE FROM COLOMBO STOCK EXCHANGE
}

\author{
Zaha Zahir ${ }^{a}$, Nadarajah Rajeshwaran ${ }^{\mathrm{b}} \bowtie$ \\ ${ }^{a}$ Department of Commerce, Faculty of Commerce and Management, \\ Eastern University, Sri Lanka \\ ${ }^{b}$ Department of Commerce, Faculty of Commerce and Management, \\ Eastern University, Sri Lanka
}

\begin{abstract}
Dividend policy is company's policy of distributing income to shareholders from earnings. Dividend policy is measured by dividend per share, dividend yield and dividend payout. Linkages between dividend policy and stock return is still obscure, notably in non-financial companies. The objective of the study is to analyze the impact of dividend policy on stock return of the non-financial companies listed in Colombo Stock Exchange. The Purposive Sample comprises of 36 non-financial companies from six sectors of Colombo Stock Exchange covering a time span from year 2014 to 2018. Non-financial sectors selected for this study include Beverage Food and Tobacco, Manufacturing, Chemicals and Pharmaceuticals, Health care, Power and Energy and Motors. Data have been collected from annual reports of companies. Statistical Package Stata 15.0 has been used to analyze and evaluate panel data using descriptive statistics, Fixed and Random Effect. Finally, Hausman test was used to select the appropriate model to explore the impact of dividend policy on stock return. This study follows the fixed effect model. In order to explore the impact of independent variables on stock return, three hypotheses have been developed and tested. Results reveal that a positive impact is found for dividend per share, while there is a negative relationship between dividend yield and stock return. The impact of dividend payout is deemed to be insignificant. In addition, it is shown that firm size, asset growth and long-term debts explain changes to stock return. It is concluded that dividend policy is relevant with stock return for the non-financial companies listed in Colombo Stock Exchange. Findings provide new insights for investors, company management and policy makers to enhance the performance in stock market.
\end{abstract}

Keywords: Colombo Stock Exchange, Dividend Payout, Dividend per Share, Dividend Yield, Share Return

\section{Introduction}

\section{Background of the Study}

Dividend policy is a firm's policy to payout earnings as dividends versus retaining them for reinvestment in the firm. It is the division of profit between payments to shareholders and reinvestment in the firm (Hussainey, Mgbame, \& Chijoke-Mgbame, 2011, p. 3). Dividend policy is a significant part of the firm's long-run financing decisions.

Dividend policy is important for both the management and shareholders, because one group has to decide and make arrangement for the payment of dividend while the other group has to receive it as a reward for their investment. Dividends are a source of income for investors as well as a representation of the performance of the company. Deciding a proper dividend policy becomes a main decision for managers and investors (Jahfer \& Hameed, 2016). The objective of dividend policy should be to maximize a shareholder's return so that the value of his investment is maximized (Pandey, 2015, p. 418). This goal can be achieved by giving shareholders a fair return on their investment. Shareholders 
wealth is reflected by the market price of the company's common stock. Dividends represents a source of income for shareholders, and it reflects the company's overall performance.

The Sri Lankan stock market, which can be delegated as a borderline market based on market capitalization, some of the time shows the highlights of a developing business sector, with generally moderate guidelines contrasted with other developing markets in the world. Companies understand that financial specialists deliver regard for their dividend returns, and that the risks of their investment may influence the valuation of the association of shares over the long run. This makes the instability of stock prices, as critical to firms for what it's worth to investors (Dewasiri \& Weerakon Banda, 2015).

There have been considerable debates on whether dividend affects the value of a share. The theoretical view differs on this issue. On the one hand, dividend increases the value of the shares. On the other hand, there is a view that dividends are bad as they result in the payment of higher taxes and thus, they reduce the shareholders wealth (Pandey, 2015, p. 439). Given all these differences, the setting of a proper dividend policy can be challenging for the companies.

Through dividend policy managers make a choice between the utilization of profit between retained earnings and dividend. Therefore, selection of a suitable policy is extremely necessary for the company. The focus of this study is to examine the impact of dividend policy on stock return of the listed non-financial companies in Colombo Stock Exchange. Attempts are made to examine the impact of dividend policy on stock return for a period of five years from 2014 to 2018. As there has been lack of research done on the impact of dividend policy on stock return of non-financial listed companies in Sri Lanka with application of latest panel data analysis, which is a highly emerging need to conduct this study.

\section{Problem Statement}

Non-financial sectors have been the most rapidly growing sectors in Sri Lanka.

Companies are faced with the problem of whether to pay a large, small or zero percentage of their earnings as dividends or finance the future investment projects. If a major portion of the profits earned by these companies are distributed as dividends then reinvestment of profit will not be possible. Deciding a proper dividend policy becomes the main decision for managers and investors (Pandey, 2015). This problem is borne out of the desire to satisfy various needs of the stockholders. Some stockholders need to receive high dividend payout now while others like to invest in the future and prefer dividends to be retained by the company and be reinvested. Due to the several interests of shareholders and management adopting a specific policy lead to an increase or decrease in the share price of the company which in fact affect the share return.

Stock price influence the stock market return and value of the shares. The previous studies conducted to identify the impact of dividend policy on share price lacks consistency and have variations in results. Friend and Puckett (1964), Richardson, Sefcik, and Thompson (1986) and Zakaria et al. (2012) found the positive association between dividends and stock market prices while Baskin found an inverse relationship between dividends and stock market prices whereas Black and Scholes (1974) and Rachim (1996 cited in Khan, 2012) failed to find out any type of relationship between the dividend and stock price.

Also, there is a methodological gap in the previous researches conducted, as the previous researches were conducted using only the basic SPSS which is not appropriate in the case of panel data. Therefore, this research provides answers to the research questions using panel data analysis.

This research sheds light onto issues and specifically determines the impact of 
dividend policy on stock return. Therefore, this study tries to answer the following research question "How does dividend policy impact on stock return of the nonfinancial companies listed in Colombo Stock Exchange?"

\section{Objectives of the Study}

- The main objective of this study is to establish the impact of firm's dividend policy on the stock return of the nonfinancial companies listed in Colombo Stock Exchange.

Secondary objectives are as follows:

- To identify the impact of dividend per share on stock return of the nonfinancial sector companies listed in Colombo Stock Exchange.

- To identify the impact of dividend yield and dividend payout ratio on stock return of the non-financial sector companies listed in Colombo Stock Exchange.

- To identify impact of control variables on stock return of the non-financial sector companies listed in Colombo Stock Exchange.

- To examine the combined impact of dividend per share, dividend yield, dividend payout and control variables such as firm size, asset growth and long term debt on stock return of the nonfinancial sector companies listed in Colombo Stock Exchange.

\section{Literature Review}

\section{Dividend Policy}

Dividend policy is a firm's policy with regards to paying out earnings as dividends versus retaining them for investment in the firm. It is the division of profit between payment to shareholders and reinvestment in the firm. Dividend policy is thus an important part of the firm's long run financing strategies. In early corporate finance, dividend policy referred to a corporation's choice of whether to pay its shareholders a cash dividend or to retain its earnings. It addressed the frequency of such payments (whether annually, semiannually or quarterly) and how much the company should, if it decides to do so, pay (Hussainey, Mgbame, \& Chijoke-Mgbame, 2011, p. 3).

\section{Factors affecting Dividend Policy}

Explaining dividend policy has been one of the toughest challenges faced by financial economists. Despite decades of study, it is yet to be completely understood the factors that influence dividend policy and the manner in which these factors interact.

\section{Dividend Yield}

It is financial ratio that shows how much a company pays out in dividend each year relative to its share price. Dividend yield is calculated as annual dividend per share divided by price per share. Dividend yield is considered as an important variable that is used by Allen and Rachim (1996), Rashid and Rahman (2009), Nazir, Nawaz, Anwar, and Ahmed (2010) and Asghar, Shah, Hamid, and Suleman (2011).

\section{Dividend Payout}

The dividend payout ratio is defined as the percentage of the company's earnings that is distributed to shareholders (Penman, 2009). Dividend Payout measures the proportion of total residual profits distributed as dividends to shareholders (Fama \& French, 1988). Consistent to Allen and Rachim (1996), Hussainey, Mgbame and Chijoke-Mgbame (2011) found a significant negative relationship between SPV and payout ratio.

\section{Dividend Per share}

Dividend per share is the sum of money declared by a company as dividend for every ordinary share outstanding. Dividend per share is the earnings distributed to ordinary shareholders divided by the number of ordinary shares outstanding (Duke, Ikenna and Nkamare, 2015).

Garba (2014) investigated the impact of dividend per share on common stock returns of the Manufacturing firms listed in the Nigeria stock exchange for a period of 
13 years found that there is a positive significant impact of dividend per share and common stock return.

\section{Size}

A research done by Lloyd, Jahera and Page (1985), showed that the size of firms played an important role in their dividend policy. That is the larger the firm the easier access to the capital market.

\section{Asset Growth}

Assets Growth is calculated by first taking the change in total assets at the end of the year and then dividing it with the total assets at the beginning of the year (Hussainey, Mgbame, \& Chijoke-Mgbame, 2011). Studies have demonstrated that the greater the growth rate and growth opportunities, the higher the firm's risk hence inducing greater stock volatility.

\section{Long term Debt}

Over the years many researchers have found that higher financial leverage is associated with greater stock volatility (Christie, 1982; Schwert, 1989). Long term debt includes interest bearing financial obligations, excluding amounts due within one year.

\section{Dividend Policy and Share Return}

According to one school of thought the amount dividend paid to shareholders is irrelevant. According to this school of thought, whether a company pays dividend or retain their profit for future reinvestment is irrelevant as a company's value is not determined by how income is distributed but rather it's on how it is invested to generate wealth for shareholders. Capstaff (2004) points out that the price of shares is inclusive of retained earnings. In situations where a firm chooses to retain their earnings as opposed to paying out divided raises the share price.
The second school of thought puts forward the argument that dividend payouts are significant and that actually affect the share returns regardless of the level that is paid. According to Gugler and Yurtoglu (2003) companies that are growing in most cases pay lower dividends and, in many instances, reinvest their earnings in new profitable projects and also finance the company's expansion activities, which lead to increased capital. Such firms' investors are usually the ones in higher tax bracket who have no immediate need for cash and who are ardent on reducing their tax burden. Companies with an enduring history of stable paying out dividends would be undesirably affected by a decreased or lack of payout on dividend; while in another instance increased or additional payout on the dividend would positively affect the company (Khan, 2012).

\section{Conceptual Framework and Formulation of Hypotheses}

Conceptual framework of the study is shown in Figure 1 and operationalization is given in the Table 1.

\section{Formulation of Hypotheses}

The hypotheses were formulated based on the previous studies pertaining to dividend policy and stock price.

\section{Dividend Yield}

A holistic study by Baskin (1989) using data from 1967 to 1986 of US firms reveal a dominating negative relationship between share price and dividend yields (DY). Similar results are noted by Hussainey (2011) in a study of the UK firms from 1998 to 2007, and by Profilet and Bacon (2013). Comparable results have been obtained by Allen and Rachim (1996) in the context of the Australian stock market. 


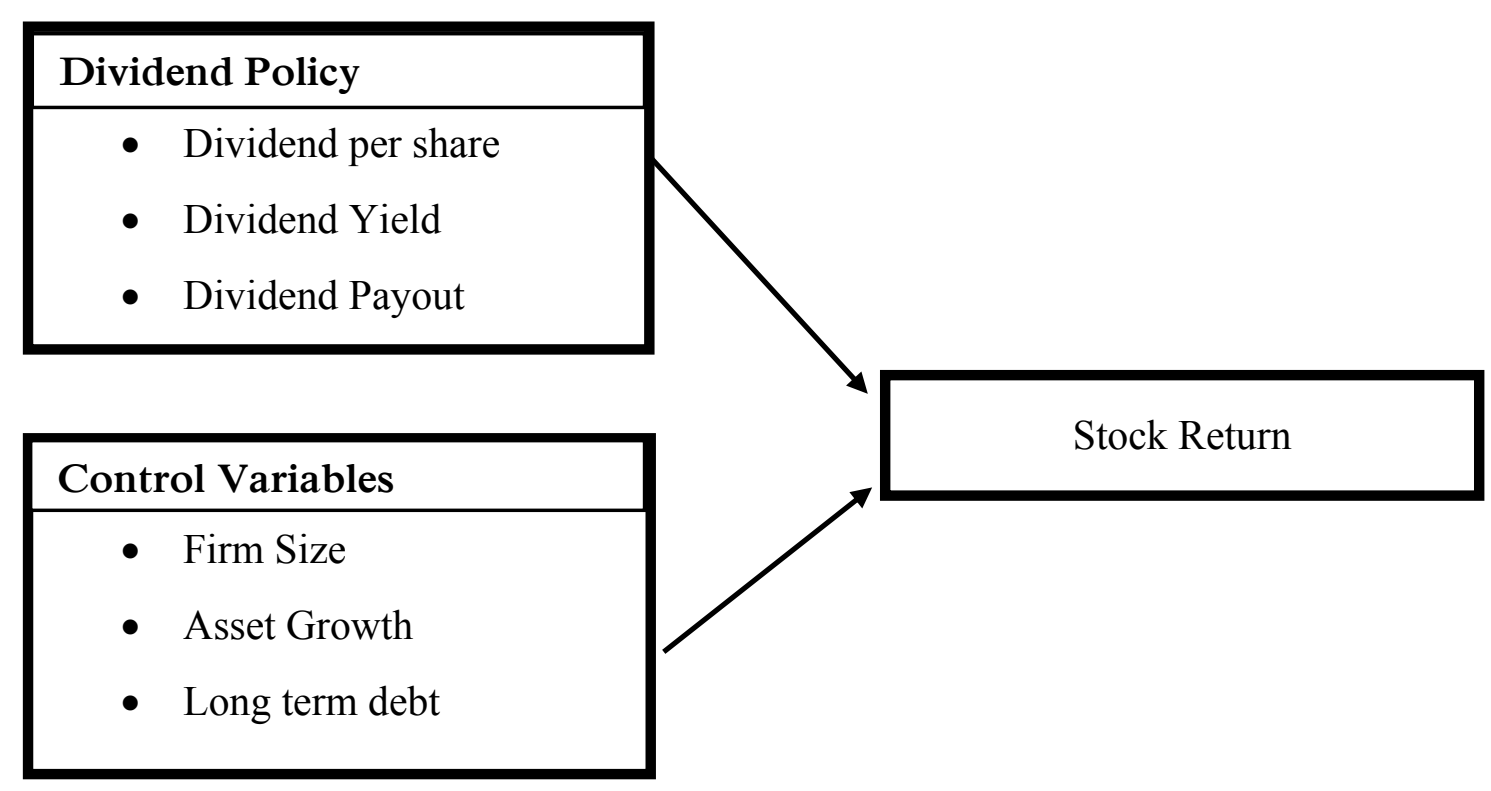

(Source: Adapted from Hussainey, Mgbame and Chijoke-Mgbame, 2011)

Figure 1: Conceptual Framework

Nazir (2010) used 73 firms listed in Karachi Stock Exchange (KSE) as the sample and studied the relationship between stock price volatility and dividend policy and results reveal that Dividend yield has a positive relationship with share price. Okafor et al. (2011) tested the impact of the dividend policy on stock price volatility with special reference to Nigerian Stock market. The results showed a statistically significant negative effect from dividend yield on price volatility. Further, a negative impact between dividend yield and stock price changes of hotels and travels companies listed in Colombo Stock Exchange is identified (Hettiarachchi \& Rajeshwaran, 2016).

Based on the above literatures following Hypothesis has been developed.

H1: There is a significant impact of Dividend Yield on Stock Return of the Non-Financial Companies Listed in Colombo Stock Exchange.

\section{Dividend Payout Ratio}

Some argues that dividends signals to investors that the company is operating effectively, while others argue that when all other variables are fixed, the payout of dividend does not effectively reduce the stock volatility (Profilet \& Bacon, 2013).
Hussainey et al. (2011) examined the effect of dividend policy on stock prices in UK. Consequences of their investigation demonstrated a significant negative connection between Dividend payout which is contrary to the finding of Baskin (1989). Hamid et al. (2017) reveal a significant positive relationship between dividend payout and share price volatility. In the context of Jordanian industrial firms, Ramadan (2013) found that increases in DY and dividend payout tend to reduce share price volatility. The empirical results of the study conducted by Hashemijoo, Ardekani abd Younesi (2012) showed significant negative relationship between share price and dividend policy. After analyzing the existing literature, the following hypothesis has been developed.

$\mathrm{H} 2$ : There is a significant impact of Dividend payout on Stock Return of the Non-Financial Companies Listed in Colombo Stock Exchange.

\section{Dividend Per share}

Garba (2014) conducted his study on the impact of dividend per share on common stock return. He found that there is a direct relationship between dividend per share and common stock return of the sampled manufacturing companies listed in the 
Nigeria Stock Exchange. A positive impact is found between dividend per share and stock price changes of hotels and travels companies listed in Colombo Stock Exchange (Hettiarachchi \& Rajeshwaran, 2016). Therefore, following Hypothesis has been formulated as per the above literature review.

H3: There is a significant impact of Dividend per share on Stock Return of the Non-Financial Companies Listed in Colombo Stock Exchange.

Table 1: Operationalization

\begin{tabular}{|c|c|c|c|c|}
\hline Category & Variable & Indicator & Notations & Measurement \\
\hline $\begin{array}{l}\text { Dependent } \\
\text { Variables }\end{array}$ & $\begin{array}{l}\text { Stock } \\
\text { return }\end{array}$ & $\begin{array}{l}\text { Stock } \\
\text { return }\end{array}$ & SR & $\frac{\left(P_{1}-P_{0}\right)}{P_{0}}$ \\
\hline \multirow[t]{3}{*}{$\begin{array}{l}\text { Independent } \\
\text { Variables }\end{array}$} & \multirow[t]{3}{*}{$\begin{array}{l}\text { Dividend } \\
\text { Policy }\end{array}$} & $\begin{array}{l}\text { Dividend } \\
\text { Per share }\end{array}$ & DPS & $\frac{\text { Total Dividends }}{\text { Number of Shares }}$ \\
\hline & & $\begin{array}{l}\text { Dividend } \\
\text { Yield }\end{array}$ & DY & $\frac{\text { Dividend per share }}{\text { Market Price per share }}$ \\
\hline & & $\begin{array}{l}\text { Dividend } \\
\text { Payout } \\
\text { Ratio }\end{array}$ & DPR & $\frac{\text { Dividend per share }}{\text { Earnings per share }}$ \\
\hline \multirow[t]{3}{*}{$\begin{array}{l}\text { Control } \\
\text { Variables }\end{array}$} & $\begin{array}{l}\text { Asset } \\
\text { Growth }\end{array}$ & $\begin{array}{l}\text { Asset } \\
\text { Growth }\end{array}$ & $\mathrm{AG}$ & $\frac{\left(T A_{1}-T A_{0}\right)}{T A_{0}}$ \\
\hline & $\begin{array}{l}\text { Firm } \\
\text { Size }\end{array}$ & Firm Size & FS & $\begin{array}{c}\text { Log } 10(M V \text { of the } \\
\text { firm) }\end{array}$ \\
\hline & $\begin{array}{l}\text { Long } \\
\text { term } \\
\text { debt }\end{array}$ & $\begin{array}{l}\text { Long } \\
\text { term debt }\end{array}$ & $\mathrm{DA}$ & $\frac{\text { Long Term Debt }}{\text { Total Assets }}$ \\
\hline
\end{tabular}

Source: Adapted from Hussainey, Mgbame and Chijoke-Mgbame (2011)

\section{Methodology}

Panel data technique is used to analyze the relationship between dividend policy and stock return. A panel database was constructed for the 36 non-financial companies listed in Colombo Stock Exchange for a period of five years from 2014 to 2018. In order for a firm to be included in the sample, it must have completed financial data that are available for the entire period of study and firms that regularly paid dividend is taken into consideration. The model was evaluated annually over five-year period to measure the impact of dividend policy on stock return. In this study the Statistical Package (Stata 15.0) has been used to analyze the data. The collected data can be analyzed using different methods such as Univariate and Bivariate analysis, Unit Root Test, Random and Fixed Effect and Hausman Test.

\section{Data presentation and analysis}

To check the stationarity of the panel data, Levin-Lin-Chu test has been conducted. The panel data contains a strongly balanced dataset of 36 companies for a period of five years. Before starting any regression analysis, variables has to be tested for stationarity as this would provide the accurate result on regression analysis. Levin-Lin-Chu test assumes that each individual unit in the panel shares the same AR(1) coefficient, but allows for individual effects, time effects and possibly a time 
trend.

Six variables have been tested using the statistical software Stata 15.0. Lag for ADF regression was selected based on AIC to find out the optimal lag. As shown in

Table 2, test results of Levin-Lin-Chu revealed that at the significance level of $5 \%$, the null hypothesis is rejected, as the pvalue is 0.0000 . Therefore, the alternative hypothesis is accepted and the study concludes that all the variables are stationary during the period in consideration for this study.

In panel data analysis Hausman test is used to choose between fixed effect model and random effect model. With the purpose of having robust results, researchers use Hausman test to check the suitable model for interpretation of results. If the $p$-value is less than 0.05 , then the appropriate model is the fixed effect model. On the other hand, if the p-value is greater than 0.05 then random effect model should be selected for analysis.

According to the Table 03 Hausman Test results, the p-value is 0.0000 with the significance of $5 \%$ it is concluded that the null hypothesis is rejected and the alternative hypothesis is accepted. Hence, the fixed effect model is suitable for this study. The Table 04 Fixed effect results shows that stock market return has a positive significant relationship with dividend per share while significant negative relationship with dividend yield. The dividend yield has negative and indirect relationship with stick return.

$P$ value shows the level of significance. It is evident from the fixed effect model that the level of significance is insignificant at $5 \%$. Also this has been supported by $t$ statistics, as its value is less than \pm 2 . Whereas variables like dividend payout ratio, asset growth and long-term debt have insignificant negative relationship and firm size has a positive significant relationship with stock market return respectively. $\mathrm{F}$ $(6,138)=3.90$ and $p$-value $0.000<0.0013$, this signifies that the model is significant.
The constant statistic is -2.599014 . The $\beta$ coefficient value indicates the individual contribution of each predictor to the model. The $\beta$ coefficient for dividend per share is 0.0091649 . This result explains on average, if dividend per share increases by one unit, the share return will be increased by 0.0091649 units. The $\beta$ coefficient for dividend yield is -3.374665 . This result explains on average, if dividend yield increases by one unit, the share return will be reduced by -3.374665 units. The $\beta$ coefficient for dividend payout is 0.030284 . This result explains on average, if dividend payout increases by one unit, the share return will be reduced by 0.0091649 units. Here the relationship between dividend payout and stock return is negative and it concludes that decrease in dividend payout ratio leads to a decrease in share return.

The $\beta$ coefficient for dividend firm size is 0.1216165 . This result explains on average, if firm size increases by one unit, the share return will increase by 0.1216165 units. The $\beta$ coefficient for asset growth is 0.0261361 . This result explains on average, if asset growth increases by one unit, the share return will reduce by -0.0261361 units. The $\beta$ coefficient for long term debt is -0.0225613 . This result explains on average, if long term debt increases by one unit, the share return will reduce by 0.0225613 unit.

Determination of coefficient $\left(\mathrm{R}^{2}\right)$ is 0.3949 which indicate that for the sample $39.49 \%$ of the variation of the dependent variable (share return) can be explained by the independent variables (dividend per share, dividend yield, dividend payout, firm size, asset growth and long-term debt. 
Table 2: Unit Root Test

\begin{tabular}{|c|c|c|c|c|c|}
\hline Variable & & Statistic & p-value & $\begin{array}{l}\text { Alternative } \\
\text { Hypothesis }\end{array}$ & Results \\
\hline \multirow{2}{*}{$\begin{array}{l}\text { Dividend Per Share } \\
\text { (DPS) }\end{array}$} & Unadjusted $\mathrm{t}$ & -8.9170 & \multirow[t]{2}{*}{0.0000} & \multirow[t]{2}{*}{ Accepted } & \multirow[t]{2}{*}{ Dividend Per Share is stationary } \\
\hline & Adjusted $t^{*}$ & -7.4327 & & & \\
\hline \multirow[t]{2}{*}{ Dividend Yield (DY) } & Unadjusted $\mathrm{t}$ & -19.4282 & \multirow[t]{2}{*}{0.0000} & \multirow[t]{2}{*}{ Accepted } & \multirow[t]{2}{*}{ Dividend Yield is stationary } \\
\hline & Adjusted $t^{*}$ & -19.4943 & & & \\
\hline \multirow[t]{2}{*}{ Dividend Payout (DP) } & Unadjusted $\mathrm{t}$ & $-1.3 e+02$ & \multirow[t]{2}{*}{0.0000} & \multirow[t]{2}{*}{ Accepted } & \multirow[t]{2}{*}{ Dividend Payout is stationary } \\
\hline & Adjusted $t^{*}$ & $-1.4 \mathrm{e}+02$ & & & \\
\hline \multirow[t]{2}{*}{ Firm Size (FS) } & Unadjusted $\mathrm{t}$ & -28.756 & \multirow[t]{2}{*}{0.0000} & \multirow[t]{2}{*}{ Accepted } & \multirow[t]{2}{*}{ Firm Size is stationary } \\
\hline & Adjusted $t^{*}$ & -29.734 & & & \\
\hline \multirow[t]{2}{*}{ Asset Growth (AG) } & Unadjusted $\mathrm{t}$ & -25.9253 & \multirow[t]{2}{*}{0.0000} & \multirow[t]{2}{*}{ Accepted } & \multirow[t]{2}{*}{ Asset Growth is stationary } \\
\hline & Adjusted t* & -25.6406 & & & \\
\hline \multirow[t]{2}{*}{ Long term debt (DA) } & Unadjusted $\mathrm{t}$ & -17.3804 & \multirow[t]{2}{*}{0.0000} & \multirow[t]{2}{*}{ Accepted } & \multirow[t]{2}{*}{ Long term Debt is stationary } \\
\hline & Adjusted $t^{*}$ & -16.5560 & & & \\
\hline \multirow[t]{2}{*}{ Share Return (SR) } & Unadjusted $\mathrm{t}$ & -21.9369 & \multirow[t]{2}{*}{0.0000} & \multirow[t]{2}{*}{ Accepted } & \multirow[t]{2}{*}{ Share Return is stationary } \\
\hline & Adjusted $t^{*}$ & -21.4237 & & & \\
\hline
\end{tabular}

Source: Survey Data

Table 3: Hausman Test

\begin{tabular}{|l|l|l|l|l|}
\hline & Fixed (b) & Random $(\mathbf{B})$ & $\begin{array}{l}\text { Difference } \\
(\mathbf{b - B})\end{array}$ & $\begin{array}{l}\text { Sqrt } \\
\left(\mathbf{d i a g}\left(\mathbf{V} \_\mathbf{b}-\mathbf{V} \_\mathbf{B}\right)\right) \text { S.E. }\end{array}$ \\
\hline Dividend Per share & 0.0091649 & -0.001039 & 0.0102039 & 0.0029998 \\
\hline Dividend Yield & -3.374665 & -0.7206412 & -2.654024 & 1.181047 \\
\hline Dividend Payout & -0.030284 & -0.0244553 & -0.0058287 & 0.0057989 \\
\hline Firm Size & 0.1216165 & 0.0467168 & 0.0748997 & 0.0553402 \\
\hline Asset Growth & -0.0261361 & 0.1665657 & -0.1927018 & 0.0582458 \\
\hline Long term debt & -0.0225613 & -0.0212171 & -0.0013442 & 0.0030305 \\
\hline
\end{tabular}

Source: Survey Data

$\mathrm{b}=$ consistent under Ho and $\mathrm{Hal}$; $\mathrm{B}=$ inconsistent under Ha, efficient under Ho; Test: Ho: difference in coefficients not systematic; $\quad$ chi $^{2}(6)=(b-B)^{\prime}\left[\left(V_{-} \text {b-V_B }\right)^{\wedge}(-1)\right](b-B) \rightarrow=33.84$ 
Table 4: Fixed Effect Model

\begin{tabular}{|l|l|l|l|l|l|l|}
\hline Share return & \multicolumn{1}{|c|}{ Coef. } & \multicolumn{1}{|c|}{ Std. Err. } & \multicolumn{1}{|c|}{ P>[t] } & \multicolumn{2}{|l|}{$[\mathbf{9 5 \%}$ Conf. Interval] } \\
\hline Dividend Per share (DPS) & 0.0091649 & 0.0032977 & 2.78 & 0.006 & 0.0026443 & 0.0156855 \\
\hline Dividend Yield (DY) & -3.374665 & 1.433035 & -2.35 & 0.020 & -6.20821 & -0.5411208 \\
\hline Dividend payout (DP) & -0.030284 & 0.0183945 & -1.65 & 0.102 & -0.0666555 & 0.0060875 \\
\hline Firm Size (FS) & 0.1216165 & 0.0581222 & 2.09 & 0.038 & 0.0066914 & 0.2365417 \\
\hline Asset Growth (AG) & -0.0261361 & 0.1715774 & -0.15 & 0.879 & -0.3653968 & 0.3131246 \\
\hline Long term debt (DA) & -0.0225613 & 0.0197987 & -1.14 & 0.256 & -0.0617093 & 0.0165868 \\
\hline Constant & -2.599014 & 1.305053 & -1.99 & 0.048 & -5.179499 & -0.0185278 \\
\hline
\end{tabular}

Source: Survey Data

Prob $>$ chi $2=0.0000$

Table 5: Model Summary of Fixed Effect

\begin{tabular}{|l|l|}
\hline $\mathrm{F}(6,138)$ & 3.90 \\
\hline Prob $>$ F & 0.0013 \\
\hline R-squared & 0.3949 \\
\hline Adj R-squared & 0.2151 \\
\hline \multicolumn{2}{|l|}{ Source: Survey Data }
\end{tabular}


The Adjusted $\left(\mathrm{R}^{2}\right)$ is 0.2151 . Adjusted $\left(\mathrm{R}^{2}\right)$ indicates that it is an adjustment of the $\mathrm{R}$ square that penalizes the addition of extraneous predictor to the model. The adjusted $\left(\mathrm{R}^{2}\right)$ is smaller than $\left(\mathrm{R}^{2}\right)$ statistic because it downward adjusts the $\left(\mathrm{R}^{2}\right)$ statistic when additional variable of limited significance are added to a model (Table 5).

Hypotheses one and two are accepted while hypothesis three is rejected. Based on the Table 4 and above data, the equation for the regression model is as follows.

$S R=-2.599014+0.009161649(D P S)-$ $3.374665(D Y)-0.030284(D P)+$

$0.1216165(F S)-0.0261361(A G)-$ $0.0225613(D A)+\varepsilon$

\section{Conclusions}

The first objective of this study is to identify the impact of dividend per share on stock return of the listed non-financial companies in CSE. It has been found that dividend per share has a significant positive impact on stock return. Additionally, this finding is consistent with the previous literature works.

The second objective of this study is to identify the impact of dividend yield and dividend payout on the stock return of the listed non-financial companies in CSE. According to the fixed effect model there is a significant negative relationship between dividend yield and stock return.Also, it can be found that dividend payout has negative and insignificant relationship with stock return.

The third objective of this study is to identify the impact of control variables on the stock return of the non-financial companies listed in CSE. Control variables used in this study includes firm size, asset growth and longterm debt. Firm size was calculated based on the natural logarithm of market capitalization. It can be concluded from the study that firm size has a significant positive relationship with stock return.

Also, the asset growth and long-term debt has a negative and insignificant relationship with stock return.

The fourth objective of this study is to identify the overall impact of dividend policy on stock return. The findings on this research indicate overall there is significant impact of dividend policy on stock return. The p-value of fixed effect model is 0.0013 which indicates that model is significant and dividend policy has impact on stock return.

The $\mathrm{R}$ square is 0.3949 . This means in this study dividend policy can account $39.49 \%$ of the variation in stock return. The other $60.51 \%$ of the variation in stock return cannot been explained by dividend policy alone. Therefore, it can be concluded that there are other variables that influence the stock return. This provides the investors and the decision makers with information about future share return.

\section{Recommendations}

Based on the conclusions and findings this section provides recommendation which will relevant to non-financial sector companies. Non-financial companies can have a consistent cash dividend arrangement since this would increase investors return over the long run because of its ability to impart positive signs to the potential investors thus expanding the demand for shares.

Also, it is recommended for non-financial companies to adopt strategies to improve their earnings as it has been noticed that some companies paid dividend even though they had an earning loss. Therefore, policy makers should incorporate the role of earning per share in accessing the dividend per share of the firm.

Investors can seek companies based on market capitalization as it can be found that companies with higher market capitalization paid higher dividend while companies with lower market capitalization paid low dividend and the share return for the investors are high in companies with higher market capitalization. 


\section{References}

Allen, D. E., and Rachim, V. S. (1996). Dividend Policy on Stock Price Volatiliy: Australian Evidence. Applied Financial Economics 6(2), pp.175-188 DOI: $10.1080 / 096031096334402$.

Asghar, M., Shah, S. Z., Hamid, K., and Suleman, M. T. (2011). Impact of Dividend Policy on Stock Price Risk: Empirical Evidence from Equity Market of Pakistan. Far East Journal of Psychology And Business, 4(1), pp.4552

Retrieved from:https://www.researchgate.net/pub lication/227436441_Impact_of_Divide nd_Policy_on_Stock_Price_Risk_Emp irical_Evidence_from_Equity_Market _of_Pakistan.

Black, F. and Scholes, M. (1974). The effect of dividend yield and dividend policy on common stock prices and returns. Journal of Financial Economics, 1(1), pp.1-22.

Baskins, J. (1989). Dividend Policy and the Volatility of common Stocks. The Journal of Portfolio Management, 15(3), pp. 19-25 DOI: 10.3905/jpm.1989.409203.

Capstaff, J., Klaeboe, A., and Marshall, A. P. (2004). Share Price Reaction to Dividend Announcements: Empirical Evidence on the signaling Model from the Oslo Stock Exchange. Multinational Finance Journal, 8(1), pp.115-139 DOI: 10.17578/8-1/2-4.

Christie, A. (1982). The stochastic behavior of common stock variances: Value, leverage and interest rate effects. Journal of Financial Economics, 10 (4) pp. $407-432$

Dewasiri, N. J., and Weerakon Banda, Y. K. (2015). Dividend policy and stock price volatility: An error corrected approach.
Asia Pacific Journal of Management, 11(3), pp.166-170 DOI: 10.1177/2319510X15588387.

Duke, S.B., Ikenna, I. D. and Nkamare, S. E. (2015). Impact of Dividend Policy on Share Price Valuation in Nigerian Banks. Archives of Business Research, 3 (1)

Fama, E. F., and French, K. R. (1988). Dividend Yields and Expected Stock Return. Journal of Financial Economics, pp.3-25 DOI: 10.1016/0304-405X(88)90020-7.

Friend, I. and Puckett, M. (1964). Dividends and Stock Prices. The American Economic Review, 54, pp.656-682.

Garba, A. (2014). The Impact of DividendPer- Share on Common Stock Returns: A Re-Examination. International Journal of Managerial Studies and Research, 2(2), pp.75-79 DOI: $10.2307 / 2327767$.

Gugler, K. and Yurtoglu, B. (2003). Corporate governance and dividend pay-out policy in Germany. European Economic Review, 47 (4), pp. 731-758

Hashemijoo, M., Ardekani, A. and Younesi, N. (2012). The impact of dividend policy on share price volatility in the Malaysian stock market. Journal of Business Studies, 4(1), pp.111-129.

Hettiarachchi, U. S., and Rajeshwaran, N. (2016). The Impact of Dividend Policy on Stock Price: An Empirical Evidence from Hotels and Travels Companies Listed in Colombo Stock Exchange. International Conference in Accounting Researchers and Educators. Retrieved from: http://repository.kln.ac.lk/handle/1234 56789/16407. 
Hussainey, K., Mgbame, C. O., and ChijokeMgbame, A. M. (2011). Dividend policy and share price volatility: UK evidence. The Journal of Risk Finance, 12(1), pp.57-68 DOI: $10.1108 / 15265941111100076$.

Jahfer, A., and Hameed, M. (2016). Dividend policy and share price volatility: Evidence from Colombo stock market. International Journal of Managerial and Financial Accounting, 8, pp. 98-108 DOI: 10.1504/IJMFA.2016.077947.

Khan. (2012). Effect of Dividends on stock prices- A case of Chemical and Pharmaceutical Industry of Pakistan. Scientific and Academic publishing, pp. 141-148

DOI:

10.5923/j.mm.20120205.02.

Khan, M. Y., and Jain, P. K. (2005). Financial Management- Text, Problems, and Cases. New Delhi: Tata McGraw Hill Publishing Co. Ltd Retrieved from: https://books.google.com/books/about/ Financial_Management_Text_Problem s_And_C.html?id=CXMm5_LOtdEC.

Lloyd, W. P., Jahera, J. S., and Page, D. E. (1985). Agency costs and Dividend Payout ratios. Financial Review, 20(3), Retrieved from: https://www.jstor.org/stable/40472822.

Nazir, M. S., Nawaz, M. M., Anwar , W., and Ahmed, F. (2010). Determinants of Stock Price Volatility in Karachi Stock Exchange: The Mediating Role of Corporate Dividend Policy. International Research Journal of Finance And Economics Issue, 55, pp. 100-107 Retrieved from: https://www.researchgate.net/publicati on/268049844_Determinants_of_Stoc k_Price_Volatility_in_Karachi_Stock_
Exchange_The_Mediating_Role_of_C orporate_Dividend_Policy.

Pandey, I. M. (2015). Financial Management 11th Edition. New Delhi: Vikas Publishing House Pvt Ltd Retrieved from: https://books.google.mv/books/about/F inancial_Management_11th_Edition.ht $\mathrm{ml}$ ?id=vahDDAAAQBAJ\&redir_esc= y.

Penman, S. H. (2009). Valuation Models An Issue of Accounting Theory. Retrieved from:https://www.semanticscholar.org/ paper/Valuation-Models-\%3A-AnIssue-of-Accounting-TheoryPenman/3e49cf43c61376a5a28669ca1 b8d6e1fc531e 063 .

Profilet, K. A., and Bacon, F. W. (2013). Dividend Policy and Stock Price Volatility in the U.S. Equity Capital Market. Proceedings of ASBBS (pp. 113). Retrieved from: https://www.researchgate.net/publicati on/313143575_Dividend_Policy_and_ Stock_Price_Volatility_in_the_US_Eq uity_Capital_Markets.

Ramadan, I. Z. (2013). Dividend Policy and Price Volatility: Empirical Evidence from Jordan, International Journal of Academic Research in Accounting, Finance and Management Sciences, 3 (2), pp. 15-22

Rashid, A., and Rahman, A. A. (2008). Dividend Policy and Stock Volatility: Evidence from Bangladesh. Journal of Applied Business and Economics, 8(4), pp. 71-81 DOI: 10.1109/CHUSER.2012.6504314.

Richardson, G., Sefcik, S. E. and Thompson, R. (1986). A test of dividend irrelevance using volume reactions to a change in dividend policy. Journal of 
Financial Economics, 17(2), pp. 313333

Schwert, G. W. (1989). Why Does Stock Market Volatility Change Over Time?, Journal of Finance, 44 (5), pp. 11151154
Zakaria, Z., Muhammad, J. and Zulkifli, A. H. (2012). The impact of dividend policy on the share price volatility: Malaysian construction and material companies. International Journal of Economics and Management Sciences 2(5), pp.1-8. 